\title{
Vulnerability of the old community Observations from Wuhan, China
}

\author{
Xiaolin LAO, Huazhong University of Science and Technology, China
}

\begin{abstract}
In the post-COVID-19 era, it is necessary for cities to increase their level of resilience to cope with unexpected risks. How can they improve their level of resilience? This article will stress research on the most vulnerable units in cities and further identify key vulnerability indicators of these units. The study area is in Wuhan, China, and the research object is the old community. In China, urban governance generally follows the "City - District - Street - Community" model, the "street" is the city's cell, and the community is the basic unit of urban functioning. Meanwhile, grassroots (community) governance is divided into a more fine-grained pattern: "Community - Subcommunity - Community grid - Building." Unlike the internationally accepted term "slum," the old community is a specific concept in China. It usually refers to communities with many vulnerable people living in, whose functional decline, structural dilapidation, environmental deterioration, because of the long period since its construction. So, the old community is the most vulnerable part of the community, and its level determines the upper limit of the city's resilience (Cannikin Law). First, this paper systematically reviews the development of Chinese communities after 1949. It classifies old communities into three categories: the street committee system, the danwei system, and the community-based system. Second, three dimensions of resilience: physical environmental, social environmental, and individual consciousness dimensions, were derived by examining internationally sophisticated resilience assessment methods. Third, the paper observes old communities in Wuhan under these three dimensions, elaborating a series of vulnerability indicators and find out reasons. Besides, data were collected from participant observation, archives, interviews, newspapers, and published reports. This paper aims to provide a reference on how to fundamentally improve cities' resilience levels, namely, to start with their basic units and address the weakest parts.
\end{abstract}

\section{Keywords}

Vulnerability, The old community, Resilience

\section{Introduction}

\section{Conceptual Clarification}

1) Resilience

The term "resilience" is derived from the Latin word "resilio," which means to return to the original state after an external stimulus (Translated et al.). It also reveals the capacity of a system exposed to risks to plan, absorb, recover, and adapt to maintain its basic structure and function, and to recover from disasters. Community resilience is the conceptual, technical and connotational manifestation of urban resilience on a more precise spatial scale (Peng et al., 2018). Ostadtaghizadeh et al. (2015) proposed the UN definition of community resilience: "ability of a system, community, or society exposed to hazards to resist, absorb, accommodate to and recover from the effects of a hazard in a timely and efficient manner 
including through the preservation and restoration of its essential basic structures and functions (UNISDR, 2012, Ostadtaghizadeh et al., 2015)."

2) Vulnerability

The common perception of vulnerability is that in an uncertain risk or disaster environment, individuals, systems are damaged by strong external disturbances that are difficult to recover from (Adger and Kelly, 1999, Enxin, 2016, Songhua and Ling, 2014). Notably, humans' own socio-economic disadvantages make them extremely vulnerable to natural events, and this vulnerability does not originate from the natural environment itself (O'KEEFE, 1976). Typically, vulnerability is defined as the degree to which a system is likely to suffer damage to its sub-systems and components when exposed to external pressures (threat or disturbance) (Change, 2007).

3) The old community

The term "community" means social groups and social relationships that are highly homogeneous, closely related in demographics, and share identical values (Tönnies, 1912). Besides, "Community" may imply a geographic location, such as a neighborhood, village, or county; it may also denote a social unit that shares a sense of location. In China, the community is the unit of urban grassroots governance, and its equivalent is the rural grassroots unit: the village. Thus, in this study, the community is considered a social group (community) with common interests and a sense of identity, basing on administrative regions and social association.

The word "old" has two implications: long existence time and change over time. In conclusion, the old community in this study refers to those built between 1949 and 2000. Their initial functional state is affected by various factors such as physical, economic, and social aspects as their service life grows (Xinquan and Bo, 2011). And its functions are unable to meet the needs of the residents effectively, the structure is increasingly dilapidated, and the environment is chaotic and disorderly (Chao, 2011). Accordingly, the old community is a relative concept, it is temporal and relative, and with the development of society, the new community will eventually enter the old community category. The "new" community is an opposite concept to the "old" community, which could name "the general community" that was built after 2000 and is the community of the community-based system.

The old community is not a "slum" and not necessarily a historic district. A similar concept to "slum" is "squatter." Although the term "slum" does not exist in the official documents of the socialist system, scholars defined shantytowns in China as the "slum," in which a large number of agricultural laborers move to the cities as mobile populations then build shantytowns. These shacks are temporary brick or sheetrock structures without property ownership certificates and not recognized by the government. On the contrary, the old community is a formal housing estate with a property ownership certificate. Although the old community mostly has a long history, they are not necessarily historic districts. Namely, they do not necessarily have a unique local style or represent the past life of a city.

\section{Background and research question}

Since 2020, the world has been struggling to control COVID-19. Commendable that China's urban system achieves rapid response times by relying on authoritarian power and recovered well in 2021. However, it is still unforgettable 85,973 cases and 4,634 deaths in October 2020. This number revealed how the urban unequal historical state has led to incredible vulnerability during crises. As Cannikin Law points out, any weakness can prevent the entire urban structure from fully functioning. Especially the most vulnerable part determines the upper limit of the system's resilience, and the most disadvantaged groups bear the most incredible burden on health, social affairs, and the economy. Besides, the community is the urban grassroots, the basic unit of cities. 
Moreover, the old community is the vulnerable part of the community, which affects the community's resilience network overall city, and then hampers the city's resistance to crises. That is why enhancing the old community's resilience could improve urban resilience at the root. Thus, behind the death number during a crisis lies the urban system's action logic. To reveal this logic, we should not only focus system during and after the crisis but also move the perspective to the historical state before the crisis because the historical state determines whether the system's stock resists pressure.

In summary, by focusing on the historical state of the urban system's most vulnerable units, we could know the urban resilience's upper limit, then deriving the logic of urban crisis action. In other words, this paper draws a picture back on the historical state of old communities to validate the logic of their crisis response and then sketch their collective action, that is, the entire city's action.

Accordingly, a series of vulnerable indicators can identify the old community's inner vulnerability under the resilience dimension. These vulnerability indicators of the old community are critical/prominent because they have a higher vulnerability than those of the general community. And the research question was proposed: What are the key vulnerability indicators of the old community?

\section{Methods and Content}

Qualitative research methods were used for this study.

Thus, the first step of this paper collates the resilience dimensions that can guide community vulnerability analysis. The method is the literature review to extract the primary and secondary dimensions of resilience from well-established community resilience models/methods/frameworks to guide participatory community observation in Wuhan, China.

The second step is to draw a historical picture of the categories and characteristics of old communities in China. The method was document review publicly available in China, such as guidelines, laws and regulations, reports and literature, investigating China's community development significant events, named the old communities with those events as nodes, and summarized the characteristics.

The third step is to find out what causes the indicator's vulnerability in the old community, highlighting the parts different from the general community. (Since knowing the critical vulnerability indicators requires an understanding of what contributes to these vulnerability indicators). The previous two steps' results of the literature and document review formed the basis for the participatory observation. Then, (1) Before observing Wuhan old communities, the author's theoretical foundation and rooted experience constructed pre-imagine of Wuhan's overall community. (2) During the

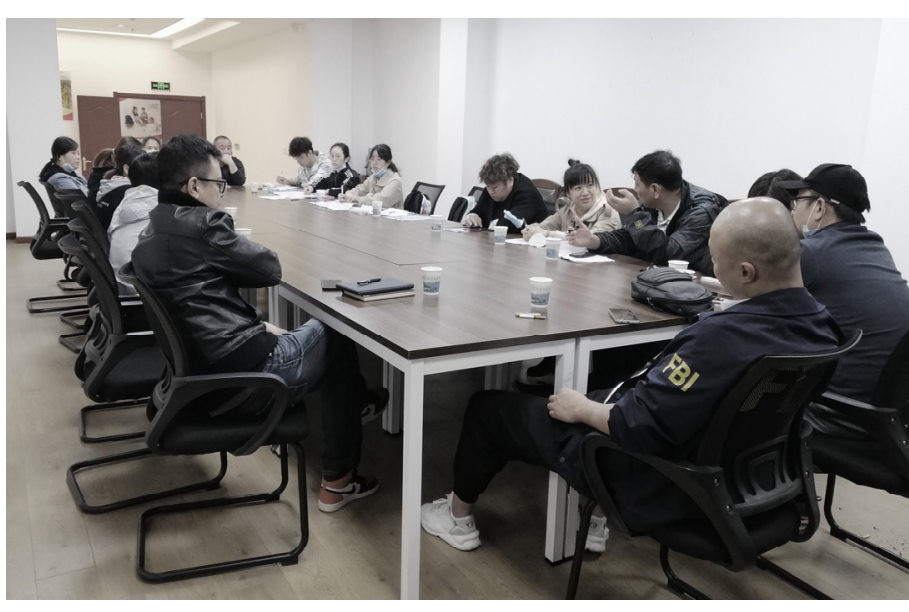

Figure 1. FDG in Hanzheng street.

Source: Author's own photograph. observation period, Hanzheng street was selected as the focus group, key Informant interviews, and household interviews source in conjunction with the interview method (Table 1). (3) The experiences of other communities (outside Hanzheng street) were from the authors' participatory research, not described elaborately in this paper. Data were obtained from community contacts, WeChat articles, government documents, and so on. 
Table 1. Interview method of the third step.

\begin{tabular}{|c|c|c|c|}
\hline Stakeholder & $\begin{array}{l}\text { Date/last } \\
\text { time }\end{array}$ & $\begin{array}{l}\text { Number } \\
\text { of people }\end{array}$ & $\begin{array}{l}\text { Fieldwork } \\
\text { method }\end{array}$ \\
\hline Residents & One week & 32 & $\begin{array}{l}\text { Household } \\
\text { Interview (HI) }\end{array}$ \\
\hline $\begin{array}{l}\text { Planning experts (4), Secretary H and Secretary B of } \\
\text { Hanzheng Street Office (2), heads of RCs and GPOs in } \\
\text { every sub-community (6), community-grid staffs (2), } \\
\text { Resident Representatives (2) }\end{array}$ & $\begin{array}{l}\text { November } \\
5 \text { th, } 2020\end{array}$ & 17 & $\begin{array}{l}\text { Focus Group } \\
\text { Discussion } \\
\text { (FGD) }\end{array}$ \\
\hline Community grid staffs & & 3 & $\begin{array}{l}\text { Key Informant } \\
\text { Interview (KII) }\end{array}$ \\
\hline Total & & 52 & \\
\hline
\end{tabular}

\section{Three dimensions of community resilience}

This chapter reviews thought the dimensions of resilience assessment models internationally used through conceptual and empirical proof methods.

Table 2. Resilience dimension summary.

\begin{tabular}{|c|c|}
\hline $\begin{array}{l}\text { First level } \\
\text { dimension }\end{array}$ & $\begin{array}{l}\text { Summary of literature review of community resilience assessment model's } \\
\text { dimensions }\end{array}$ \\
\hline $\begin{array}{l}\text { Physical } \\
\text { Environmental } \\
\text { Dimension }\end{array}$ & $\begin{array}{l}\text { Physical capital, Obtaining Information, Recovery potential, Natural Capital, Nature } \\
\text { and Environment, Health \& Wellbeing and Information \& Communication, Critical } \\
\text { Services and Infrastructure Resilience, Environmental, Natural, Energy, Water + } \\
\text { Food, Materials + Artifacts, Physical (resources and infrastructure), Infrastructure } \\
\text { \& Environment, Natural Capital, Climate, Environmental Capability, Resource } \\
\text { Capability, Physical Protection, Structure and technical measures, Risk and } \\
\text { Vulnerability Levels, Response and Recovery Resources, Information \& } \\
\text { Communication, Physical Capital, Housing/Infrastructure, Community Capital, } \\
\text { Transportation, Environment / Ecosystem, Transportation and Housing, Emergency } \\
\text { Services, Safety during earthquakes, Availability During Response and Recovery, } \\
\text { Natural Systems and Exposure, Land Use and Structure Design, Planning, Design, } \\
\text { Warning and Evacuation, }\end{array}$ \\
\hline $\begin{array}{l}\text { Social } \\
\text { Environmental } \\
\text { Dimension }\end{array}$ & $\begin{array}{l}\text { Social, Social capital, Governance, Legal and Institutional Procedures, Emergency } \\
\text { Preparation, Response and Recovery Plan and Development Plan, Regulations, } \\
\text { Regime, Politics, Maintenance + Operations, Leadership and Strategy, Social } \\
\text { Cohesion and Connections, Community, Institutions, Strategies, Policies, Plans and } \\
\text { Procedures, Existing Initiatives, Community Engagement, Environmental and } \\
\text { Natural Resource Management, Social Protection, Financial Instruments, Planning } \\
\text { Systems, Disaster Risk Reduction, Conflict Management, Social Protection, Natural } \\
\text { Resource Management, Public Goods Management, Community Connectivity, } \\
\text { Planning \& Response \& Recovery Procedures, Emergency Planning, Social } \\
\text { Connections, Connections and Care, Disaster Management, Risk Assessment, Risk } \\
\text { Management and Vulnerability Reduction, Disaster Preparedness and Response, } \\
\text { Economic Development, Economic Capital, Economy, Finance, Capital Structure, } \\
\text { Social + Economic Dynamics, Economic Environment, Financial, Organized } \\
\text { Government Services, Economic Development, Socio-Cultural Capital, Social } \\
\text { Services, Institutional Priorities for Disaster Risk Reduction, Assessment and } \\
\text { Monitoring of Risks, Enhanced Response Preparation, Emergency Response, }\end{array}$ \\
\hline
\end{tabular}




\begin{tabular}{|c|c|}
\hline & Disaster Recovery, Budget Allocation and Funding Processes, \\
\hline $\begin{array}{l}\text { Individual } \\
\text { Consciousness } \\
\text { Dimension }\end{array}$ & $\begin{array}{l}\text { Tools and Processes, Self-reliance, Mitigation, Risk mitigation, Risk awareness, } \\
\text { Social Cohesion / Connectedness, Awareness and Capacity Building, Human, } \\
\text { Culture, Human Capital, Hazard Prevention Hazard Adaptation + Mitigation, } \\
\text { Community Cohesion, Productivity, Health + Diversity, Applied Creativity, } \\
\text { Innovation + Exploration, Health and Wellness, Knowledge and Health, Technology } \\
\text { and Learning, Planning Systems, Individual Access to Information and Data, Human } \\
\text { Participation, Human Health and Well-Being, Sustainable Livelihoods, Physical and } \\
\text { Mental Health, Social and Economic Well-Being, Effective Risk Exchange } \\
\text { Information, Integration and Participation at all Stages of Organization, Potential } \\
\text { for Change, Knowledge and Education, Personal Disaster Preparation and } \\
\text { Response, Labor Markets, Population and Demographics, Lifestyles and } \\
\text { Community Capacity, Employment and the Economy, Resident Awareness, } \\
\text { Knowledge \& Innovation \& Education, Personal Preparedness, Risk Knowledge }\end{array}$ \\
\hline
\end{tabular}

Source: Collated from CRC (Parsons and Morley, 2017), CRDSA (Alshehri et al., 2015), NIST (Cauffman, 2015), RELi (Sharifi, 2016), TCRI (Perfrement and Lloyd, 2015), CoBRA (Plan), FCR (IFRC, 2014), CRS (Community and Institute, 2013), LDRI (Orencio and Fujii, 2013), USAID (Frankenberger et al., 2013), CDRST (Arbon, 2014), BCRD (Chandra et al., 2011), CART (Chandra et al., 2011), Resilus (Miles and Chang, 2011), ICBRR (Kafle, 2010), BRIC (Cutter et al., 2014), CDRI2 (Shaw and Sharma, 2011), CERI (Team, 2010), CDRI (Peacock et al., 2010), CRI2 (Sherrieb et al., 2010), CRI (Sempier et al., 2010), PEOPLES (Renschler et al., 2010), CRT (Localize, 2009), SPUR (Poland, 2009), DFID (Twigg, 2009), CARRI (Cutter et al., 2008a), Hyogo (UNISDR, 2008), USIOTWT (Program and Courtney, 2007), THRIVE (Davis et al., 2005), CRM (Enterprise et al., 2000).

This paper will comply with the Cutter to refine them more fine-grained into three community resilience dimensions: physical environmental, social environmental, and individual consciousness dimensions (Cutter et al., 2014, Cutter et al., 2016, Cutter et al., 2008b). Each of these dimensions is divided into several sub-dimensions, and these secondary dimensions are subdivided into several resilience indicators (Table 2).

1) The Physical environmental resilience dimension is divided into three dimensions: mitigation space, key-mitigation facility, and building performance. Mitigation space is reflected as the potential for community disaster mitigation space to resist risks; the key-mitigation facility is reflected in the resilience of community disaster mitigation facilities and the ability to respond to risks; Building performance is reflected in the community's potential buildings and environment to cope with and resist risks.

2) The social environmental resilience dimension contains three dimensions: governance, autonomy, and civic engagement. Governance and autonomy are reflected in top-down and bottom-up governance levels. The former one of management level to resist risks and the latter one of self-management levels to generate resilience; civic engagement is reflected in using connectable social forces and transformable internal community forces to enhance community resilience (community groups, residents, specialist teams, and social organizations are involved in community resilience building).

3) The individual consciousness resilience dimension is divided into cultural awareness and manpower skills. Cultural awareness is reflected in the perceived risk, emergency, and crisis response sensitively, and the community's sense of belonging and identity, response, and sustainable development potential for post-disaster recovery; manpower skills are represented by the stability of the demographic structure, personal habits, access to resources, and the sustainable development potential of access to resources for resisting, recovering from, and adapting to disasters. 
Resilience dimensions provide a mirror to study the most vulnerable parts. Because vulnerability is considered a symbiotic concept with resilience, a decrease in vulnerability necessarily accompanies an increase in resilience in the old community, and vice versa (Wilson, 2012). Thus, urgent issues of old communities' resilience construction can be mirrored by their key vulnerability indicator. It means that address those indicators' vulnerability can enhance their resilience.

\section{Classification and characteristics of old communities in China}

This chapter examines the classification and characteristics of old communities from a historical perspective (Figure 2).

1949 and 1978 are two acknowledged important historical epochs international, the former marking the founding of New China and the latter marking China's reform and opening up. Before 1949, communities were of baojia system, which will not be discussed in this article. From 1949 to 1978, it was the era of the planned economy. The danwei system is a grassroots organizational form that accompanies the planned economy and has a political, economic, and social trinity. The state reigned people who worked in danwei (work unit) through the danwei system; those who did not work in the danwei, no work, free people, or the vulnerable groups were ruled through the street committee system, thus achieving authoritarian control by the powerful government under dual-track parallelism. Since 1978, after the reform and opening up, China has changed from the planned economy to a socialist market economy, the danwei system has dissolution gradually. At the same time, the street committee system also fell into a management dilemma because of the significant changes at the grassroots level. With that, grassroots management step by step shifted to the community-based system. In 1989, the $7^{\text {th }}$ National People's Congress declared "Organic Law of the Urban Residents Committee of the People's Republic of China," China has officially entered the era of community-based management of grassroots. Until today, Chinese official documents distinguish between new and old communities using 2000 as the dividing line.

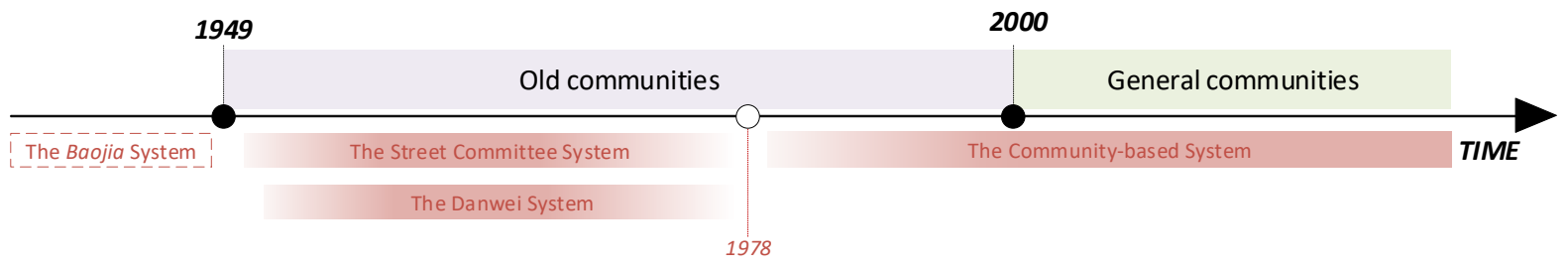

Figure 2. Community classification in historical perspective. Source: Author's own photograph.

\subsection{Old communities of the street committee system}

Communities were mainly built from 1949 to 1958, and a small number were built between 1958 and 1978. Most of these communities are self-built houses without unified planning and implementation, not to mention property management. This type of community relies on Residents' Committees (RCs; jumin weiyuanhui) for grassroots governance.

\section{Characteristic}

These communities were the earliest to be built, with no unified planning. Buildings were seriously dilapidated, and low-rise housing was predominant as well as construction density is usually high to get more living space. Streets are cluttered, with a shortage of public spaces and narrow roads, leading to driving and firefighting difficulty. Since most people gathered to live here spontaneously, and then the state established RCs to govern. As a result, people here have a sense of regional identity and strong neighborhood culture. Besides, the community business naturally grew with settling, traditional craft workshops and informal economy were widely seen.

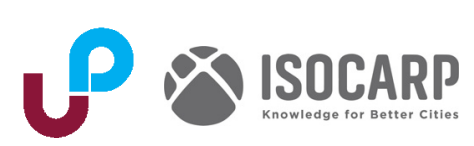




\subsection{Old communities of the danwei system}

Communities were mainly built between 1958 and 1978 and were built for one or several danwei (namely work units)' employees as welfare. This type of community relies on danwei for grassroots governance. In Wuhan City, they include not only the staff dormitories of large enterprise and scientific research institutes such as Wuhan Steel community, Wuhan Shipbuilding community, but also universities' communities in the 1980s and 1990s.

\section{Characteristic}

Compared with the street committee system ones, their planning modeled after the former Soviet Union, was logical and mixed land use (Chai and Zhang, 2010). This kind of planning provides easy access to daily facilities and significantly reduces traffic demand, thus maintaining a home - work balance. Before 1978, the danwei community was an "acquaintance society," embracing a high level of social equality and social interaction and shaping the daily-life circle based on the danwei compound (Chai, 1996), thus promoting even development and a strong sense of place and belonging (Bjorklund, 1986). These circles were the ideal spatial organization to guarantee individual needs and collective consumption, enhancing residents' life quality in an era of relative scarcity (Lu, 2006).

However, after 1978, the danwei system disappeared, and with the emergence of better-designed commercial housing, wealthy families moved out. The original residents relocated, coupled with new households moved in, and the crowd structure became complex, a sense of community identity disappeared. The social network of acquaintances maintained by the danwei and the spatial order gradually collapsed, the danwei community became a "semi-acquaintance society," and social and individual vulnerability increased. In addition, one of the significant drawbacks of the danwei system is that it fosters danwei members' dependency through resource monopolization and spatial closure. Because of inertia, these people cannot adapt to the requirements of reformed grassroots governance, lacking initiative for self-governance and participation.

Meanwhile, these communities are also not sound physical space maintained. Unlike commercial housing communities of the community-based system mentioned followed, danwei communities were no property management when they were first established. Danwei communities have lost the management and service original provided by the danwei system after the housing system reform in1978. Because of the absence of management and the passing of time, these communities gradually face aging and weak infrastructure, aging buildings, and infelicitous public spaces. The physical environmental vulnerability is increasing.

\subsection{Old communities of the community-based system}

Communities were built between 1978 and 2000, which most commercial housing. This type of community relies on GGOs for grassroots governance. GGOs, namely "two committees" in the community: Residents' Committees (RCs) and Grassroots Party Organizations (GPOs).

In 1978, China gradually transformed into a socialist market economy; with a series of social and economic changes such as housing reform and social class differentiation, commercial housing communities have appeared as a "new urban society-spatial phenomenon" in China (Bray, 2005). At this time, in response to the disappearance of the danwei system and the weakening of national hierarchical control, commercial housing communities first appeared in megacities such as Beijing, Shanghai, and Guangzhou. Then they quickly spread across China, which fundamentally ended the danwei system's dominance in the city (Tomba, 2005). 


\section{Characteristic}

This type of community emphasizes public spaces creating than before housing reform ( $\mathrm{He}$ and $\mathrm{Wu}$, 2009). Residents from different backgrounds, cultures, and traditions lack community awareness, which leads to the "stranger society" and the increasing vulnerability of the social environment. To cope with this problem, the planner weakens the single building structure and strengthens the link between the neighborhood and the courtyards, but it does not help much. Besides, open community planning was not popular in China. The planning structure of these communities is closed and inward like danwei communities to guarantee safety. But these communities have residential estate property management, and danwei communities do not. However, the quality advantage gradually fades with time, and the commercial houses become old.

\subsection{Summary}

In essence, the street committee system and the community-based system are similar. Because they both run based on grassroots quasi-governments, and the latter is a progression of the former. As communities' superiors are the street offices (SOs), communities run under SOs' authority and rely on grassroots quasi-governments to perform community management. So, these upgrades are reflected in not only grassroots quasi-governments but also SOs. For SOs, (1) SOs were not part of the official government until 1978, upgrading from quasi-government to official. Thus, their work tasks become more extensive, and then the organization body larger. For grassroots quasi-governments, (2) Firstly, grassroots quasi-governments became more emphasize co-governance. After the community-based system was established, the scene of the "two committees" (RCs and GPOs) were formed working together for grassroots governance. Whereas the street committee only depends on RCs to manage, and GPOs have not yet been established and have been acting in the name of RCs for a long time. Secondly, the work scope of grassroots quasi-governments has extended to all aspects within the community. As mentioned above, before 1978, grassroots quasi-governments (RCs) of the street committee system could only manage the residents who were not part of the danwei system. But after 1978, grassroots quasi-governments (GGOs) took over the original danwei execution function, and their jurisdiction has extended to all the residents and work units. In addition, grassroots quasi-government staff in the community-based system might have a higher management capacity than the street committee system because of the election system's update under open and reform transformation.

Every kind of community is a particular historical stage product. It seems that each of the three types of old communities separated and has its characteristics. Nevertheless, with the progression of time, an individual community now is mostly not a single type of community but a mixture of two or three types. For example, (according to FGD), in 1949, the S community of Hanzheng Street was self-built (the street committee system) by citizens at the beginning. Then, in 1964, several danwei built danwei housing in this community. By 1982, these danwei and self-built houses and were partially demolished. Add some undeveloped land, and Developers built commercial housing in that area. After finished, this community has become a mix of the street committee system, the danwei system, and the community-based, as we see nowadays. Since the Chinese official document defines from large to small, urban grassroots following the "Community - Sub-community - Community grid - Building" fine-grained pattern. For ease of understanding, a single old community probably was a mix of the different types of sub-communities as the $\mathrm{S}$ community. Nowadays, the community has gone to the era of the community-based system. Even though one old community may be a mixture of different kinds of sub-communities, it is wholly governed by GGOs at the grassroots level, rather than danwei or only RCs. Therefore, the paper looks for old communities' inner commonalities with history view, rather than widen the differences, thus comparing with the general community. 


\section{Results \& discussion: the vulnerability of old communities}

A community's resilience is related to its historical state, meaning its past community capital stock ensures that it is not overwhelmed by external pressures after a crisis strikes but quickly absorbs, recovers, and gradually adapts to a new normal. Crisis action logic means a system reacting rapidly in an immediate situation, acting when inner resources are available. If not, whether it could create a replacement with something unremarkable/possibly discarded in the normal period, or could recruit from external, which determines its survival or not. All three communities are generally of low construction and support standards, whose capital is more vulnerable than the general community, namely scarcer resources, and less stock, which determines the action logic in crisis. Then the old community shows an intense vulnerability/not resilience compared to the general community (relatively "new" community). Researching the past state can help us find reasons for the crisis-response success/failures in old communities.

Below is a summary of the vulnerability of old communities (Table 3).

Table 3. Vulnerability of old communities

\begin{tabular}{|c|c|c|c|}
\hline $\begin{array}{l}\text { Vulnerability } \\
\text { dimension }\end{array}$ & $\begin{array}{l}\text { Vulnerability } \\
\text { element }\end{array}$ & $\begin{array}{l}\text { Vulnerability } \\
\text { carrier }\end{array}$ & Probably causal factors \\
\hline \multirow{6}{*}{$\begin{array}{l}\text { Physical } \\
\text { environmental }\end{array}$} & \multirow{3}{*}{$\begin{array}{l}\text { Mitigation } \\
\text { space }\end{array}$} & $\begin{array}{l}\text { Disaster evacuation } \\
\text { centers }\end{array}$ & $\begin{array}{l}\text { Because of the long history of construction, the } \\
\text { community planning scheme is unitary and } \\
\text { backward. There is a lack of public space, even no } \\
\text { or low accessibility of disaster evacuation centers. }\end{array}$ \\
\hline & & $\begin{array}{l}\text { Disaster isolation } \\
\text { spaces }\end{array}$ & $\begin{array}{l}\text { Insufficient community green space and open } \\
\text { space. }\end{array}$ \\
\hline & & $\begin{array}{l}\text { Disaster prevention } \\
\text { and relief channel }\end{array}$ & $\begin{array}{l}\text { Road traffic is mixed, roads, public spaces and } \\
\text { emergency access are seriously occupied by } \\
\text { parking. }\end{array}$ \\
\hline & \multirow[t]{2}{*}{$\begin{array}{l}\text { Key- } \\
\text { mitigation } \\
\text { facility }\end{array}$} & $\begin{array}{l}\text { Disaster mitigation } \\
\text { service facilities }\end{array}$ & $\begin{array}{l}\text { Lack of emergency reserve space or co-location } \\
\text { with other functional areas. } \\
\text { Lack of emergency alarm system, } \\
\text { Inadequate construction of barrier-free facilities. } \\
\text { Lack of medical services, community health } \\
\text { service facilities. } \\
\text { Lack of commercial facilities, or no facilities for } \\
\text { emergency response. } \\
\text { Lack of property services. }\end{array}$ \\
\hline & & $\begin{array}{l}\text { Disaster mitigation } \\
\text { infrastructure }\end{array}$ & $\begin{array}{l}\text { The lifeline engineering systems are imperfect, } \\
\text { old, and severely damaged due to time. }\end{array}$ \\
\hline & $\begin{array}{l}\text { Building } \\
\text { performance }\end{array}$ & $\begin{array}{l}\text { building } \\
\text { performance }\end{array}$ & $\begin{array}{l}\text { The building is deteriorating, and the facility is not } \\
\text { well equipped: Lack of hallway lighting, disaster } \\
\text { prevention facilities, especially lack elevators, thus } \\
\text { the elderly and disabled people cannot respond in } \\
\text { time. }\end{array}$ \\
\hline \multirow[t]{2}{*}{$\begin{array}{l}\text { Individual } \\
\text { consciousness }\end{array}$} & \multirow[t]{2}{*}{$\begin{array}{l}\text { Cultural } \\
\text { awareness }\end{array}$} & $\begin{array}{l}\text { A sense of the } \\
\text { community identity }\end{array}$ & $\begin{array}{l}\text { Because of a large number of immigrants and a } \\
\text { floating population, coupled with the lack of } \\
\text { places and opportunities for collective activities, } \\
\text { there is no community cohesion and increased } \\
\text { friction. }\end{array}$ \\
\hline & & Resilience & Sensitivity of community stakeholders about risks, \\
\hline
\end{tabular}




\begin{tabular}{|c|c|c|c|}
\hline & & awareness & $\begin{array}{l}\text { emergencies, disasters and crises. Mainly due to } \\
\text { low stock of knowledge. }\end{array}$ \\
\hline & & Family response & $\begin{array}{l}\text { Because of family composition, family reserve, } \\
\text { family dragging, it is impossible to carry out } \\
\text { emergencies as a family unit. }\end{array}$ \\
\hline & $\begin{array}{l}\text { Manpower } \\
\text { skills }\end{array}$ & $\begin{array}{l}\text { Crisis response } \\
\text { skills }\end{array}$ & $\begin{array}{l}\text { Because individuals are not sufficiently involved in } \\
\text { disaster risk reduction exercises and training due } \\
\text { to low education level, old age or too young age, } \\
\text { or disability, and they cannot self-study mitigation } \\
\text { knowledge. }\end{array}$ \\
\hline \multirow{8}{*}{$\begin{array}{l}\text { Social } \\
\text { environmental }\end{array}$} & \multirow[t]{2}{*}{ Governance } & $\begin{array}{l}\text { Responsible } \\
\text { government } \\
\text { departments }\end{array}$ & $\begin{array}{l}\text { Misjudgment of emergency situations and policy } \\
\text { failures. } \\
\text { Excessive use of written tools for disaster } \\
\text { reduction such as documents, research, and } \\
\text { forms, resulting in reduced administrative } \\
\text { efficiency. } \\
\text { Failure of joint sectoral response to disasters. }\end{array}$ \\
\hline & & $\begin{array}{l}\text { Governance } \\
\text { dialogue }\end{array}$ & $\begin{array}{l}\text { GGOs effectiveness shows in enforcing their } \\
\text { superiors' policies and communicating the wishes } \\
\text { of the residents to superiors. }\end{array}$ \\
\hline & \multirow{3}{*}{ Autonomy } & $\begin{array}{l}\text { Planning and } \\
\text { finance }\end{array}$ & $\begin{array}{l}\text { Inadequate and unsustainable community } \\
\text { mitigation planning. } \\
\text { Lack of autonomous disaster mitigation funding } \\
\text { system. }\end{array}$ \\
\hline & & $\begin{array}{l}\text { Empowerment and } \\
\text { decentralization }\end{array}$ & $\begin{array}{l}\text { GGOs decentralize powers to residents, and GSOs } \\
\text { empower residents. }\end{array}$ \\
\hline & & $\begin{array}{l}\text { Willingness to } \\
\text { switch identities }\end{array}$ & $\begin{array}{l}\text { Available volunteers inside the community. The } \\
\text { willingness to transform from one's identity of } \\
\text { residents to volunteer, including two categories: } \\
\text { residents transform to normal volunteers, and } \\
\text { residents who join the CCP change to party } \\
\text { member volunteers. }\end{array}$ \\
\hline & \multirow{3}{*}{$\begin{array}{l}\text { Civic } \\
\text { engagement }\end{array}$} & $\begin{array}{l}\text { Social power } \\
\text { outside the } \\
\text { community }\end{array}$ & $\begin{array}{l}\text { Lack of external social power, external social } \\
\text { organizations and social volunteers are restricted } \\
\text { from entering the community to carry out } \\
\text { activities, thus the participation is not sufficient. }\end{array}$ \\
\hline & & $\begin{array}{l}\text { Resident } \\
\text { engagement }\end{array}$ & $\begin{array}{l}\text { There are fewer participatory activities within the } \\
\text { community, their sustainability is not sufficient, } \\
\text { and residents are not engaged in activities with } \\
\text { sufficient frequency. }\end{array}$ \\
\hline & & $\begin{array}{l}\text { Organizational } \\
\text { harmony }\end{array}$ & $\begin{array}{l}\text { Insufficient cooperation and communication } \\
\text { between organizations, and insufficient contact } \\
\text { between organizations and residents. }\end{array}$ \\
\hline
\end{tabular}

\subsection{Physical environmental vulnerability}

Since old communities have the attribute of being old, their physical environment must have suffered from time and become deteriorated (Figure 3). No matter how they are repaired, their performance cannot be compared with that of general communities. In addition, community planning techniques from 
the 1950 s to the 1990 s were not comparable to today's, and outdated planning and construction materials have limited the rehabilitation and renovation of old communities.
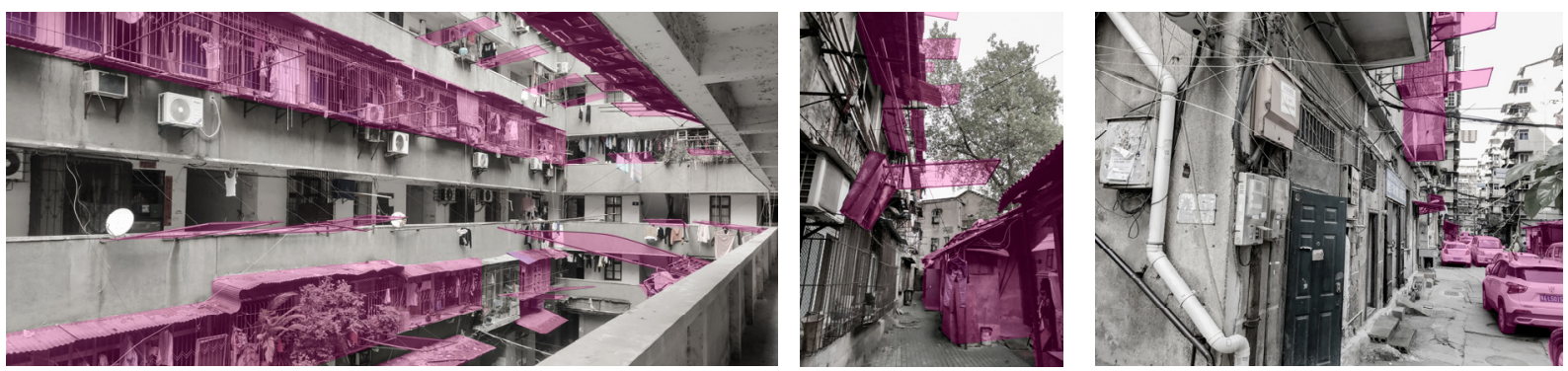

Figure 3. Physical environment chaos and decay. Source: Author's own photograph.

\section{Mitigation space}

1) Lack of disaster shelters and disaster isolation space

Reasons for the lack of disaster evacuation centers are first that past urban planning lack of considering emergency planning. Hence, the community was not equipped with reasonable disaster evacuation centers; the second was that the facilities near or within the community's centers were inadequate to meet crisis response needs. Centers can only be considered temporary post-disaster resettlement sites without basic living facilities or emergency supplies; the third was the construction and maintenance of disaster evacuation centers are costly, and the probability of a crisis is minuscule. The redundancy of evacuation centers is not guaranteed because it is contrary to the current fiscal tightening policy.

2) Disaster prevention and relief channel being blocked

In the 1970s and 1980s, Chinese people still traveled mainly by bicycle and on foot. In the 1990s, the majority of families did not possess cars. The design of old community roads primarily considered slow traffic, delivery of goods, and firefighting needs. It generally did not clearly distinguish between vehicle and non-vehicle ones, nor did road classification. As well as, it did not anticipate sufficient parking spaces.

With the improvement of living standards, the number of car ownership has increased dramatically. Hence, the open space of the present old community gave way to parking space, making the green isolation space almost zero.

The old community road structure is inward and closed, usually surrounded by buildings or separated by walls. Add to that parking occupies routes, public spaces, and emergency exits. Thus, roads cut-off, parking and motorized traffic chaos, leading relief channels are seriously blocked.

Besides, the living costs, residential conditions and space in old communities are far below the urban average. Often one or more extended families live crowded in one house. As a result, to create private spaces to improve their quality of life, residents occupy sidewalks, public areas, and rooftop spaces and build illegal structures to increase their living areas. Life passages are blocked by unauthorized constructions or clutters.

\section{Key-mitigation facility}

Infrastructure and services are crucial to ensuring life safety in emergencies. Infrastructure in old communities is often in a state of disrepair. Service facilities are also poorly configured because of old technology.

Within the public health crisis, the redundancy of health care facilities is particularly important. Community hospitals may not be available or maybe in an inferior condition in old communities. In COVID-19, the lack of community health facilities and the inequality of health services reduced the

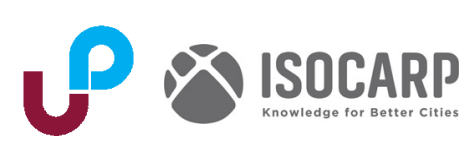


likelihood that residents would be nearby for medical care. Initially, people in old communities were terrified of COVID-19 and wanted credible support from a community hospital. But without community health care facilities and services, and only to flock to a few large hospitals, causing a collapse of health services citywide. This collapse information spread rapidly throughout the WeChat groups, exacerbating the residents' psychological stress and fear of the crisis.

"My daughter accompanied her father to the community health clinic that morning, and the surgeon there only took his temperature and told us to hurry to Zhongnan Hospital after finding the fever. My daughter drove him to the hospital and found a line full of people, not knowing which one was infected. Some people in my community said that there were many infected people in Zhongnan Hospital, and some even fell while waiting in line, and the hospital did nothing about it." (HII 1)

Notably, the jurisdiction of the entrances and exits is very crucial for COVID-19 spread control. In old communities, only sub-communities of community-based systems have property management corporations, while sub-communities of the danwei and the street committee systems generally do not. There is no dedicated staff to guard the post and manage the access without property management corporations. And it cannot count on the community staff, a too heavy workload for them to leave energy to do so. Thus, in the early stages of the epidemic, disease transmission was rampant in old communities.

"I am a grid staff of grid $\mathrm{Y}$ in the S community of Hanzheng street. In February 2020, the weather was freezing. The community has no property management, which caused an enormous burden for us. From 5:00 to 9:00, we disinfected and sterilized the community. We had a rotating shift for gate control, and I usually worked from 7:00 to 9:00. From 9:00 to 11:00, I checked door-todoor to the grid I manage, and from 11:00 to 13:00, there were three older people and two disabled families in my grid, so I had to help them buy and deliver daily supplies. From 13:00 to 17:00, I patrolled the community to see if any people were gathering. 17:00 to 19:00, I visited back the residents who were sent to quarantine to make sure they were recovering well. Before the epidemic, 19:00 was off duty, but during COVID-19, I needed to standby inside the community. Sometimes an urgent task comes down in the WeChat workgroup, and it is another day and night without rest." (KII 1)

\section{Building performance}

Buildings in old communities are in disrepair, with peeling exterior walls, no lighting in the hallways, leaking roofs, poor ventilation and lighting, and no elevators. The lack of elevators, in particular, is a deadly blow to the vulnerable in the epidemic.

"I live alone and I went downstairs once every two days before the pandemic. I would not go down if I did not have to buy groceries and take out the trash. There are no lights in our hallway, and sometimes it rains and there is water, so I have fallen down the stairs twice. During the epidemic, I did not go downstairs for two months. Luckily, I did not get infected. Mainly thanks to Xiao J (RCs staff) found me during the COVID-19 mapping process and phoned me every day to ask about my shopping needs and deliver supplies to my home. Otherwise, I do not know if I would have survived." (HII 2)

\subsection{Individual consciousness vulnerability}

Individual awareness resilience is related not only to the residents themselves and also to their families. The individual awareness dimension can be divided into two secondary dimensions: culture awareness and manpower skills. 
"Every plan in a community requires the consent of $80 \%$ of the residents and their participation in the vote. Community $\mathrm{K}$, for example, has many tenants who hardly ever participate in these plans. Therefore, many projects in the community like fire training, elevator addition, water meter relocation, and so on, cannot be implemented." (FGD)

\section{Cultural awareness}

Cultural awareness in a normal period can be seen as community identity. Community identity is a spirit of the comprehensive embodiment and centralized reflection of many components of community members' values, ideals, beliefs, and behavioral norms (Yi, 2007). Community identity is vital for community resilience, and it works in tandem with resilience awareness, which is a sensitivity for emergencies. Resilience awareness reacts within individuals and their families, and if there is community identity, they will unite not only inside but also out of the family sphere. Accordingly, in an emergency, resilience awareness was combined with community identity, achieving collective action.

Apart from the old community's inherent inadequacy in holding activities due to venue limit (physical environmental dimension), differences (social environmental dimension) in lifestyles, work backgrounds, and living standards have exacerbated (individual consciousness dimension) conflicts. Since the reform and opening up, the urban-rural integration has provided many employment opportunities, and a bounce of agriculture workers have flocked to cities. As of the low rent the old community, many migrant tenants are attracted. Wealth aboriginal families will buy better and new housing, moving out of the old community and leaving the economically disadvantaged, physically disabled, and older groups to continue to live here. Thus, most people living in old communities are migrant workers, unstable financial or low-income locals, all of them mostly have low education levels.

\section{Manpower skills}

Manpower skills are acquired through training or self-learning. Groups differentiated live together leave people in old communities without community identity and they are disobedient and uninvolved, which is hard to maintain crisis skills training. Plus, most people lack self-driven resilience awareness because of poor education. Therefore, helping them learn is not workable, and self-learning also does not, leading to enhancing manpower skills being unrealistic.

Individual residents' cultural awareness issues and a lack of manpower skills can wreak havoc on their family's coping ability. Significantly, this vulnerability can be exacerbated if the family has elderly, disabled, pregnant, or infant children. Therefore, it is suspected that the two indicators of cultural awareness and manpower skills are highly correlated.

\subsection{Social environmental vulnerability}

From the street committee system to the danwei system to the community-based system, Chinese community governance has gone through four periods. The paper compares the strength between government and society to summarize: (1) the first stage, "strong government-weak society," the community under the all-powerful control of bureaucracy; (2) the second stage, "strong governmentweak society," the community under the leadership of bureaucracy; (3) the third stage, "strong government-strong society," bureaucracy and society working together to govern community; (4) the fourth stage, "strong government - strong society," community autonomy, multi-stakeholder (including government) support.

From 1949 to 1978, the state ruled society with a single strong bureaucracy through the street committee system and the danwei System, corresponding to the first stage. After the reform and opening up in 1978, the danwei system gradually disintegrated. The market economy was established, society gradually escaped from the state power and rejuvenated. When the relationship between the state and 
society changes, the power between two shows one decreases another growth, corresponding to the last three stages. Despite the society's power growth, community autonomy cannot be achieved overnight. Because social development is still incomplete, the state still has to supplement society's incompleteness. Therefore, communities are now further divided into more fine-grained units, following the "Community - Sub-community - Community grid - Building" pattern. The community grid is a byproduct of the third stage toward the fourth stage of community governance, to realize the link between the regime and the individual.

\section{Governance}

Governance resilience needs to be maintained by responsible government departments and governance dialogue. Responsible government departments may be the various governments above the GGOs, or the government department responsible for disaster reduction, referring in particular to those government departments that have the authority to make formal disaster reduction policy decisions. The crisis is an emergency, the time left for decision-making is concise. It is very tested for the risk knowledge and local understanding of government departments to make judgments urgently. Correct decision-making and efficiency become the resilience of government departments to deal with crises.

Governance dialogue implies the effectiveness of governance GGOs effectiveness in urban areas. The difference with the previous indicator is that the previous one is formal decision making, and this one is a combination of formal and informal governance. GGO is a quasi-government without official authoritarian power, and it exercises management as an "agent" of authority. The community grid, as a relatively new product mentioned before, is under the management of GGOs and supports grassroots governance. It is also of a quasi-administrative nature. Thus, it is divided into three levels: the first level comprises leaders and staffs of GGOs, who manage and provide services to the community; the second level comprises community grid directors and grid staffs, who handle the daily affairs of the grid; the third level comprises property management corporations, building managers team and home-owners' committee, who assist in other daily affairs of the community (Renxian and Wenying, 2014). However, the community grid strengthens the autocracy to some extent. The "top-down" management system of grids contradicts the "bottom-up" self-governance ideas and demands of residents. Therefore, the community grid leads to conflict and then hampering governance dialogue.

It is hard to argue that there is a substantial difference between old and general communities on these two indicators (responsible government departments and governance dialogue). These two indicators' differences of old and new communities are probably direct or indirect effects of other indicators. In terms of the former indicator, if two communities (the old community the general community) share the same crisis decisions under the same street office. If not, these decisions may be different. Therefore, this indicator is more influenced by region than whether the community is new or old. Regarding the latter indicator, elections for GGOs leaders/staff are now held citywide, and there is a rotation system. GGOs members working in an old community this year may reassign to a general community next year. For example, old communities possess a worse physical environment, resulting in a larger workload for GGOs than general communities. These people have less energy to organize community participation or perfunctorily in epidemic mapping, indirectly affecting government dialogue indicators. The paper points out these two indicators here because they are important in both new and old communities.

\section{Autonomy}

The autonomy of old communities is weak in its plan \& finance, empowerment \& decentralization, and willingness to switch identities. Notably, Grassroots Support Organizations (GSOs) support grassroots by participating in community development projects and programs in direct action with social groups and organizations and establishing progressive partnerships with community multi-stakeholders (Balbis, 2001, 
Boglio Martínez, 2008). GSOs can facilitate community self-governance, and old communities are often more likely than the general community to lack the support of GSOs.

1) Plan \& finance

As mentioned before, Chinese community governance is still transitioning from the third to the fourth stage, and communities have not yet reached the level of self-governance. With extremely vulnerable physical environments, old communities cannot even guarantee a basic standard of living, not to consider sound community disaster mitigation development. In addition, because of the shortage of physical environmental carriers and probably lack GSOs to act as a delegate for investments, old communities rarely have good income-generating initiatives. Hence, no preparation and no funding for community disaster mitigation planning are normal and understandable.

2) Empowerment \& decentralization

GGOs are related to decentralization. GGOs are the "agent" of authoritarian power at the grassroots level in China. Namely, the superior government passes authority to the community and exercises it through GGOs. Then, GGOs use participatory means, decentralize power to various stakeholders. They also need to ensure that community elites and community organizations do not intercept power.

GSOs are related to empowerment and are mainly oriented to two categories: residents and GGOs. GSOs empower residents with manpower skills. Besides, GSOs empower GGOs with management, organizational coordination, crisis \& risk resistance, and so on Therefore, if communities lack GSOs, then the ability to enhance residents and GGOs is not guaranteed. When a crisis hits, individuals and families do not have the risk consciousness or capacity. And GGOs, as community management organizations, have no organizational capacity, too.

Due to venue availability, it is more difficult for old communities to attract GSOs to root in than the general community. It does not exclude that some areas have policy incentives to attract GSOs to root these communities. Besides, the decentralization of GGOs in the old community may not be as smooth as in the general community due to the venue's limitations.

3) Willingness to switch identities

Volunteers include that inside and outside the community. Under the autonomy dimension, available volunteers inside depend on the willingness of residents to switch identities, whatever normal volunteer or party member volunteer. Party member volunteers are those who join the Chinese Communist Party (CCP) and are willing to serve as volunteers providing services for residents. Those who are not party members are normal volunteers. In the same situation, the willingness of party members to convert volunteers will be stronger. However, situations differ between old and new communities. As the prerequisite for volunteering is can to satisfy one's own needs before helping others. Most people who live in old communities struggling to make ends meet or themselves still need to be assisted. So, the number of volunteers in old communities is much lower than in the general community.

\section{Civic engagement}

The civic engagement was affected by management, financial, intellectual, and physical factors. At first, the engagement of external social power, including individual external volunteers, various organizations, departments, NGOs, the CCP associations, corporations, and non-profit organizations, has to consider the utility of GSOs and GGOs. GSOs recruit resources outsides based on their robust social network. If GSOs do not support the old community, it is brutal for GGOs to cross the community to get help from social volunteers. When social power is recruited, GGOs perform management to ensure these external volunteers go into the community orderly in crises. 
Secondly, resident engagement is influenced by objective and subjective factors. It is objective that there is no venue available for the old community's residents to engage. Besides, the government, corporations, or foundations fund not all civic engagement, but a large portion is self-funded. In old communities, residents may not be able to afford it. Low education residents bear no subjective awareness to engage, compounded by the fact that old communities have many elderly or disabled people who are likely unable to move freely.

"I am very willing to participate in various community engagement activities. But I have been laid off, and my monthly state-issued low-income subsidy is only 1,500 RMB. I usually go to those activities organized by RCs or NGOs that do not cost me anything, but I am not willing to participate in those activities pay my own." (HI 3)

Moreover, organizational harmony is built through communication, the practice of community projects, and activities. Without organizations and individuals to engage, the interaction between organizations and organizations and between organizations and individuals is limited. They are unable to understand each other's working habits and preferences, access local needs, and express their willingness to improve. As a consequence, organizational harmony cannot be constructed.

Correspondingly, GGOs may not understand the residents' needs without sufficient activities, which weakens their autonomy capacity and strengthens the administrative attributes, and then affects decentralization. That means GGOs only know how to implement policies rather than create activities according to residents' needs. It is also challenging to develop a sense of community identity to promote collective action in crises, and at last old communities possess low social cohesion.

\section{Conclusion}

This paper hits the nail on the head by identifying the vulnerability indicators in the most vulnerable units of Wuhan city. It is hoped that it can provide ideas for other cities internationally, starting from the short boards of the barrel to analyze the reasons for their deficiencies, thus enhancing the city's resilience.

Although this paper tries to look for commonalities among different types of old communities, thus identifying the differences between old communities and general communities, but the facts do not smooth exactly work out as envisioned. The commonality between different types of old communities lies eminently in the vulnerability of the physical environment and individual consciousness. Nevertheless, in the social environmental dimension, this commonality is not so significant. Then it is even more difficult to compare this dimension to the old community and the general community.

First, as a carrier for community engagement, the physical environment closely influences social and individual consciousness dimensions. The old communities have been built longer than the general community and have suffered from a depleted physical environment, affecting the other two dimensions. Second, Low educational attainment in old communities affects the ability of individuals and families to cope, and demographic differentiation prevents communities from collaborating, which in turn leads to the vulnerability of the individual consciousness dimension. Third, the social environmental dimension is more complex than the first two dimensions. Objective \& subjective, GSOs, GGOs, and the CCP play an essential role in it. This fact makes not distinguish the old and general communities prominently separately in some indicators of this dimension. The old community suffers difficulty rooting GSOs due to objective venue constraints (not excluding policy facilitation). Therefore, among the indicators related to GSOs, this indicator vulnerability of the old community is more significant than the general community. GGOs staff in old communities have a greater workload, making it impossible to divert energy to community autonomy. When a resident joins the CCP, he prefers to serve his community as a volunteer. 
But when he is in health trouble, then he definitely could not serve. Whether party members or not, people in old communities have a more significant proportion of vulnerable groups, constraining the number to participate in community building or volunteer. Thus, old communities generally have a higher vulnerability of social environmental dimensions than the general community, except that the causes are non-linear.

Furthermore, as we all know, there are many kinds of crises, not only public health crises like COVID-19 but also natural disasters like earthquakes, tsunamis, tornadoes, manufactured crises like nuclear power station explosions, 9/11 attacks, and chemical plant leaks. With all-hazard scenarios, there are a series of indicators related to the resilience of old communities. Some indicators are more critical in specific crises, and it is hard to ignore the impact of the vulnerability of these indicators on a specific crisis. This paper tries to make these key indicators available for all kinds of crises. However, the discussion in COVID-19 makes them inevitably more applicable to public health crises, which is a limitation of this paper.

\section{Acknowledgements}

This research did not receive any specific grant from funding agencies in the public, commercial, or notfor-profit sectors.

\section{References}

ADGER, W. N. \& KELLY, P. M. 1999. Social vulnerability to climate change and the architecture of entitlements. Mitigation and adaptation strategies for global change, 4, 253-266.

ALSHEHRI, S. A., REZGUI, Y. \& LI, H. 2015. Delphi-based consensus study into a framework of community resilience to disaster. Natural Hazards, 75, 2221-2245.

ARBON, P. 2014. Developing a model and tool to measure community disaster resilience. Australian Journal of Emergency Management, The, 29, 12-16.

BALBIS, J. 2001. NGOs, governance and development in Latin America and the Caribbean, Unesco-Management of Social Transformations Program.

BJORKLUND, E. M. 1986. Economic Geography, 62, 19.

BOGLIO MARTíNEZ, R. A. 2008. Grassroots support organizations and transformative practices. Journal of Community Practice, 16, 339-358.

BRAY, D. 2005. Social space and governance in urban China: The danwei system from origins to reform, Stanford University Press.

CAUFFMAN, S. A. 2015. Community resilience planning guide for buildings and infrastructure systems.

CHAI, Y. W. 1996. Geographical Research, 15, 30.

CHAI, Y. W. \& ZHANG, Y. 2010. Urban Planning International, 25, 20.

CHANDRA, A., ACOSTA, J., HOWARD, S., USCHER-PINES, L., WILLIAMS, M., YEUNG, D., GARNETT, J. \& MEREDITH, L. S. 2011. Building community resilience to disasters: A way forward to enhance national health security. Rand health quarterly, 1.

CHANGE, I. C. 2007. Climate change impacts, adaptation and vulnerability. Contribution of working group II to the fourth assessment report of the Intergovernmental Panel on Climate Change. Summary for policymakers-Brussels-April.

CHAO, J. 2011. Research on the design of external environment renovation in old urban communities. Nanjing Forestry University.

COMMUNITY \& INSTITUTE, R. R. 2013. Building resilience in America's communities: Observations and implications of the CRS pilots. Community \& Regional Resilience Institute Oak Ridege, TN.

CUTTER, S. L., ASH, K. D. \& EMRICH, C. T. 2014. The geographies of community disaster resilience. Global Environmental Change, 29, 65-77.

CUTTER, S. L., ASH, K. D. \& EMRICH, C. T. 2016. Urban-Rural Differences in Disaster Resilience. Annals of the American Association of Geographers, 106, 1236-1252. 
CUTTER, S. L., BARNES, L., BERRY, M., BURTON, C., EVANS, E., TATE, E. \& WEBB, J. 2008a. Community and regional resilience: Perspectives from hazards, disasters, and emergency management. Geography, 1 , 2301-2306.

CUTTER, S. L., BARNES, L., BERRY, M., BURTON, C., EVANS, E., TATE, E. \& WEBB, J. 2008b. A place-based model for understanding community resilience to natural disasters. Global Environmental Change, 18, 598606.

DAVIS, R., COOK, D. \& COHEN, L. 2005. A community resilience approach to reducing ethnic and racial disparities in health. American Journal of Public Health, 95, 2168-2173.

ENTERPRISE, C. F. C., LEWIS, M. \& ROWCLIFFE, P. 2000. The community resilience manual: a resource for rural recovery \& renewal, Port Alberni, BC: Centre for Community Enterprise.

ENXIN, G. 2016. Defensiveness, vulnerability and resilience: the triple variation in urban safety management. Chinese Public Administration, 11, 105-110.

FRANKEnBERGER, T., MUELLER, M., SPANGLER, T. \& ALEXANDER, S. 2013. Community resilience: Conceptual framework and measurement feed the future learning agenda. Rockville, MD: Westat, 1.

HE, S. \& WU, F. 2009. China's emerging neoliberal urbanism: Perspectives from urban redevelopment. Antipode, 41, 282-304.

IFRC 2014. IFRC Framework for Community Resilience. International Federation of

Red Cross and Red Crescent Societies, Geneva, Switzerlan.

KAFLE, S. K. Integrated community based risk reduction: an approach to building disaster resilient communities. Annual International Workshop \& Expo on Sumatra Tsunami Disaster \& Recovery, 2010. 1-20.

LOCALIZE, B. 2009. Community resilience toolkit: A workshop guide for community resilience planning. Oakland, CA: Bay Localize.

LU, D. F. 2006. Remaking Chinese Urban Form: Modernity, Scarcity and Space, 1949-2005.

MILES, S. B. \& CHANG, S. E. 2011. ResilUS: A community based disaster resilience model. Cartography and Geographic Information Science, 38, 36-51.

O'KEEFE, P. 1976. Taking the" Naturalness" out of" Natural Disaster". Nature (London), 260, 566-567.

ORENCIO, P. M. \& FUJII, M. 2013. A localized disaster-resilience index to assess coastal communities based on an analytic hierarchy process (AHP). International Journal of Disaster Risk Reduction, 3, 62-75.

OSTADTAGHIZADEH, A., ARDALAN, A., PATON, D., JABBARI, H. \& KHANKEH, H. R. 2015. Community disaster resilience: A systematic review on assessment models and tools. PLoS currents, 7.

PARSONS, M. \& MORLEY, P. 2017. The Australian natural disaster resilience index. Australian Journal of Emergency Management, The, 32, 20.

PEACOCK, W. G., BRODY, S. D., SEITZ, W. A., MERRELL, W. J., VEDLITZ, A., ZAHRAN, S., HARRISS, R. C. \& STICKNEY, R. 2010. Advancing resilience of coastal localities: Developing, implementing, and sustaining the use of coastal resilience indicators: A final report. Hazard Reduction and Recovery Center, 1-148.

PENG, C., DEZHI, L., HONGXIA, C. \& QINGBIN, C. 2018. Review and perspectives on community resilience research: concepts, dimensions and evaluation. Modern Urban Research, 11.

PERFREMENT, T. \& LLOYD, T. 2015. The Resilience Index: the modelling tool to measure and improve community resilience to natural hazards.

PLAN, D. R. R. A. Community Based Resilience Assessment (CoBRA) Conceptual Framework and Methodology.

POLAND, C. 2009. The resilient city: Defining what San Francisco needs from its seismic mitigation polices. San Francisco Planning and Urban Research Association report, San Francisco, CA, USA.

PROGRAM, U. S. I. O. T. W. S. \& COURTNEY, C. 2007. How Resilient is Your Coastal Community?: A Guide for Evaluating Coastal Community Resilience to Tsunamis and Other Hazards, US Agency for International Development.

RENSCHLER, C. S., FRAZIER, A. E., ARENDT, L. A., CIMELlARO, G. P., REINHORN, A. M. \& BRUNEAU, M. 2010. A framework for defining and measuring resilience at the community scale: The PEOPLES resilience framework, MCEER Buffalo, NY.

RENXIAN, Z. \& WENYING, W. 2014. From Grid Management to Cooperative Governance: An Analysis of the Evolution of the Community Governance Model in China during the Transition Period. Journal of Xiamen University(Arts \& Social Sciences), 1.

SEMPIER, T., SWANN, D., EMMER, R., SEMPIER, S. \& SCHNEIDER, M. 2010. Coastal community resilience index: A community self-assessment. Mississippi-Alabama Sea Grant Consortium. 
SHARIFI, A. 2016. A critical review of selected tools for assessing community resilience. Ecological indicators, 69, 629-647.

SHAW, R. \& SHARMA, A. 2011. Climate and disaster resilience in cities, Emerald Group Publishing.

SHERRIEB, K., NORRIS, F. H. \& GALEA, S. 2010. Measuring capacities for community resilience. Social indicators research, 99, 227-247.

SONGHUA, W. \& LING, Z. 2014. Study on the construction of a comprehensive urban vulnerability assessment system. Journal of Soochow University(Philosophy \& Social Science Edition), 5, 30-37.

TEAM, A. S. 2010. Community economic resilience index. Birmingham, UK.

TOMBA, L. 2005. Residential Space and Collective Interest Formation in Beijing's Housing Disputes. The China Quarterly, 934-951.

TöNNIES, F. 1912. Gemeinschaft und gesellschaft: grundbegriffe der reinen Soziologie, K. Curtius.

TRANSLATED, S. B. M., YIZHANG \& HAILONG, L. The concept of resilience revisited. Urban Planning International.

TWIGG, J. 2009. Characteristics of a disaster-resilient community: a guidance note (version 2).

UNISDR 2008. Indicators of Progress. Guidance on Measuring the Reduction of Disaster Risks and the Implementation of the Hyogo Framework for Action. United Nations International Strategy for Disaster Reduction (UNISDR), Geneva.

UNISDR, W. 2012. Disaster risk and resilience. Thematic Think Piece, UN System Task Force on the Post-2015 UN Development Agenda.

WILSON, G. 2012. Community resilience and environmental transitions, Routledge.

XINQUAN, Z. \& BO, P. 2011. Study on the development of public space in the process of organic regeneration of old communities. Science \& Technology Information, 19.

YI, S. 2007. Moral capital: a new vision of current community spirituality. Journal of Chongqing University of Technology(Social Science), 4. 